\title{
Economic valuation of Blue Lagoon Tourism Village Widodomartani Sleman
}

\author{
Fikri Nurrachman Ernawan and Rika Harini* \\ Environmental Geography Department, Faculty of Geography, Universitas Gadjah Mada, Yogyakarta, 55281, Indonesia
}

\begin{abstract}
Blue Lagoon Tourism Village is one of the developing tourism villages in Sleman Regency. Blue Lagoon Tourism Village has great potential to become an advanced tourism village when viewed from the aspect of attraction, accessibility, facilities, and ancillary services (4A). Research objectives are to calculate the economic valuation using the travel cost method and calculate bequest value of the Blue Lagoon Tourism Village. This research conducted by sequential explanatory technique that uses quantitative and qualitative methods in sequence. Assessment of the economic value of tourism activities in the Blue Lagoon analyzed using the Individual Travel Cost Method (ITCM). Multiple linear regression tests were also conducted to obtain the value of regression function. Otherwise calculation of bequest value is carried out using the contingency valuation method (CVM) in the form of willingness to pay (WTP). Potential economic value of Blue Lagoon Tourism Village is IDR $6019052924 \mathrm{yr}^{-1}$, while actual economic income is IDR 1802827450 or $23.05 \%$ of economic potential. Bequest value of Blue Lagoon is IDR $610521783 \mathrm{yr}^{-1}$ with 6.45 ha of area, so bequest value based on area is IDR 94650758 .
\end{abstract}

\section{Introduction}

Tourism is all activities related to the object of attraction with the aim of refreshing physical and psychological conditions. Tourism is an important sector that can significantly boost the economy, especially in archipelagic countries such as Indonesia [1]. Developments in the tourism sector can also encourage other sectors to grow, especially in tourist receiving areas. The tourism sector can be used as a solution by the government in economic development. That is because the tourism sector can touch certain economic groups up to the lower classes [2].

Tourism is one of the leading sectors in Sleman Regency. One of policy made by the Sleman Regency Government is maximizing tourism potential by developing tourism villages. Village tourism is a program that combines attractions, accommodation, and facilities and is presented in a unity of community life with prevailing traditions. Tourism village is a village that is developed without changing what already exists and is more likely to explore potential by utilizing all aspects contained in the village [2].

Figure 1 Illustrate that Sleman Regency has 37 tourism villages. Huge amount of tourism village indicates that Sleman Regency has great potential in developing the tourism sector through tourism villages. The rapid growth that occurred in tourism on a village basis occurs because people have switched from conventional tourism products to tourism products related to nature, culture, and also environmentally friendly [3]. Blue Lagoon Tourism Village located in
Widodomartani Village, Sleman Regency is one of the developing tourism villages in Sleman Regency. Blue Lagoon Tourism Village has great potential to become an advanced tourism village when viewed from the aspect of attraction, accessibility, facilities, and ancillary services (4A).

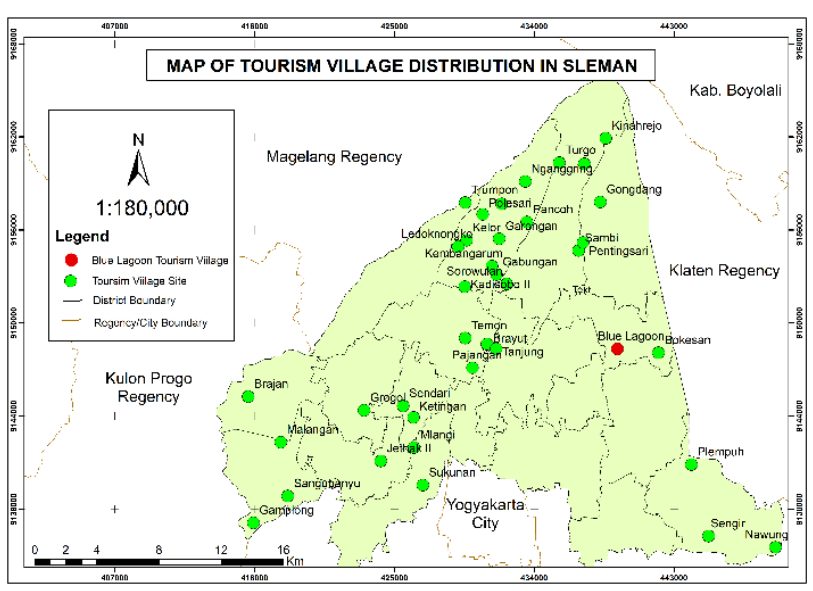

Fig. 1. Map of Tourism Village in Sleman Regency

Tourism activities in the Blue Lagoon Tourism Village can have both positive and negative impacts on the community and the physical environment. According research from Sulistyowati in 2017, positive impact arising from the existence of tourism activities in the Blue Lagoon Tourism Village is an increase in community income from food stand, lodging, tour

\footnotetext{
* Corresponding author: rikaharini@ugm.ac.id
} 
guides, and parking. These tourism activities can also have a negative impact especially on the physical environment that comes from garbage produced by tourist activity. Another impact that can arise in the form of conversion of agricultural land as a consequence of the expansion of the tourist area in the village [4].

The research objective are to calculate the economic valuation using the travel cost method and calculate the heritage value of the Blue Lagoon Tourism Village. The results of this study can be used as a consideration for doing conservation efforts and the decision making of the tourism village management. Conservation, and preservation need to be done so that tourism can be sustainable for future generations.

\section{Research method}

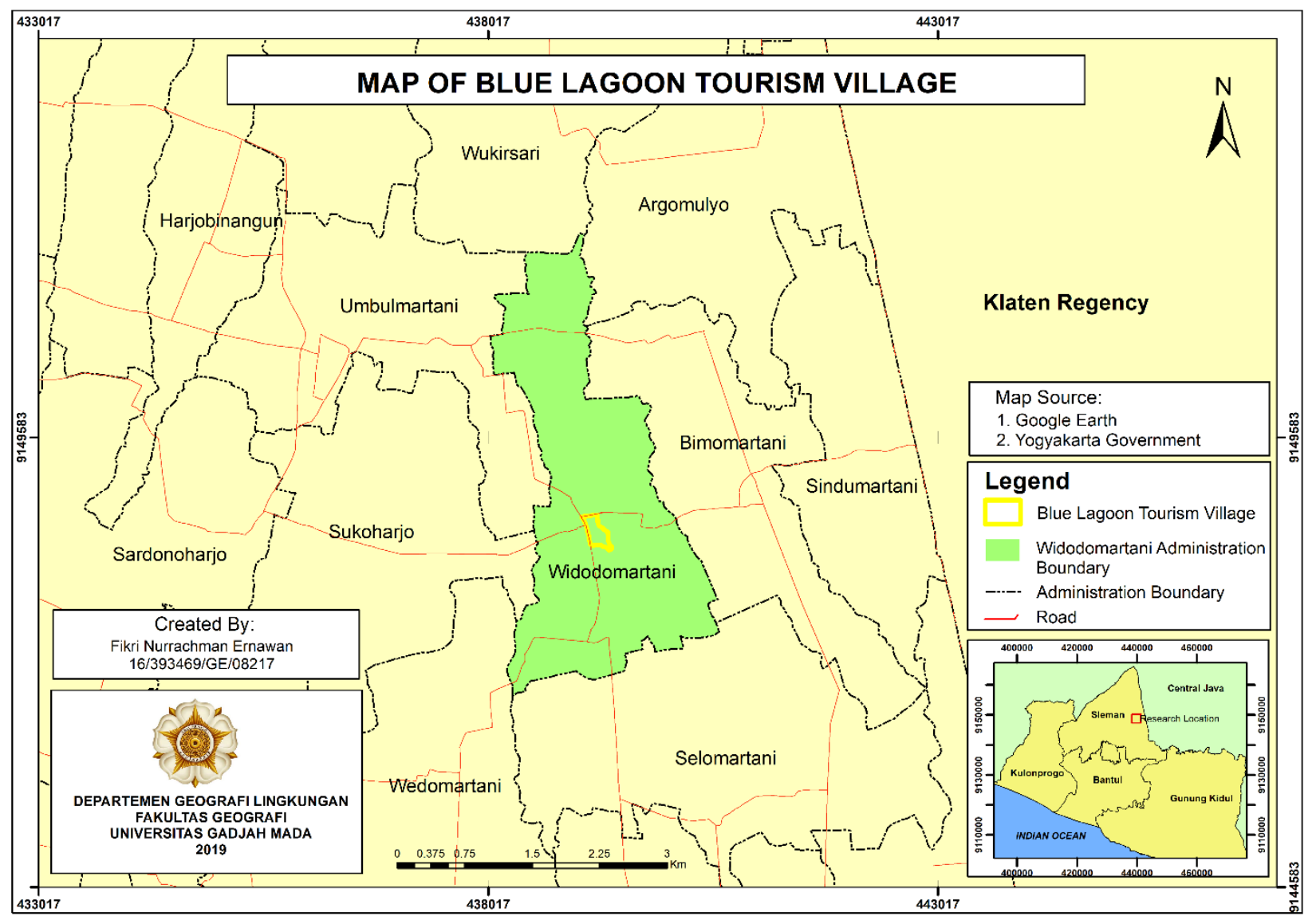

Fig. 2. Study area map

\subsection{Study area}

Blue Lagoon Tourism Village actually located in small region called "Dusun" Dalem. This research located in Widodomartani Village, Ngemplak District, Sleman Regency, Special Region of Yogyakarta (Figure 2). Blue Lagoon Tourism Village is around $17 \mathrm{~km}$ from the center of Yogyakarta City or about $50 \mathrm{~min}$ if using a four-wheeled vehicle. Blue Lagoon Tourism Village chosen as the study location because this location has great potential to continue to develop when viewed from social conditions. Blue Lagoon established since the end of 2014 and was inaugurated by the Sleman Government on March 22, 2015. Blue Lagoon Tourism Village Management is carried out independently by the community in "Dusun" Dalem. The management structure of the tourism village is led by Chief Manager with supervision and direction from the Widodomartani Village and also Sleman Government.

\subsection{Population and sample}

The research conducted by sequential explanatory technique. Sequential explanatory technique is a research technique that uses quantitative and qualitative methods in sequence. Quantitative method are used to calculate the economic value and the value of inheritance in tourism activities in the Blue Lagoon Tourism Village. Qualitative method used by interviewing managers to find out deep information about current and future utilization plans in the Blue Lagoon Tourism Village.

Object of the research is tourists visiting Blue Lagoon Tourism Village and the manager of Blue Lagoon Tourism Village. Samples to tourists were taken using the quoted accidental sampling method. Sampling method is using accidental sampling because the population cannot be determined. Determination of the sample is based on the formula that conducted by Lameshow [5]. 


$$
n=\frac{Z a \cdot P \cdot Q}{L^{2}}
$$

Description:

$$
\begin{array}{ll}
\mathrm{n} & : \text { Minimum sample required } \\
\mathrm{Z} \alpha & : \text { Standard value of confidence level } \\
\mathrm{P} & : \text { Prevalence of outcome } \\
\mathrm{Q} & : 1-\mathrm{P} \\
\mathrm{L} & : \text { Accuracy }
\end{array}
$$

\subsection{Tourism economic valuation}

An assessment of the economic value of tourism activities in the Blue Lagoon Tourism Village analyzed using the Individual Travel Cost Method (ITCM) supported by the Statistical Package for Social Sciences (SPSS) software. Multiple linear regression tests were also conducted to obtain the value of regression function. Consumer surplus (CS) value is calculated using the value of the regression equation using one independent variable such as travel cost $(X 1)$. Results of these calculations are then calculated with a limited integral equation. The lower limit used in the integral calculation is limited to the lowest travel costs ( $p 1)$, while the upper limit incurred by highest travel cost ( $p 2)$. The cost of excess consumers obtained is still individual value, so it is necessary to add value to the economic potential per year by multiplying the value of excess consumers with the average number of visitors to the tourist village per year.

$$
c s=\int_{p 0}^{p 1} f(X 1 x) d X 1
$$

\subsection{Bequest value calculation}

Calculation of bequest value is carried out using the contingency valuation method (CVM) in the form of willingness to pay (WTP). The method is carried out to determine the extent of tourists' willingness to pay for conservation, preservation, and care activities in the "Blue Lagoon" Tourism Village. The average value of the PAPs calculated is then multiplied by the average number of visitors per year to identify the amount of economic value that can be utilized for conservation and conservation policies or programs in the "Blue Lagoon" Tourism Village. The formula used to determine the WTP value is illustrated from equation below [6]

$$
E W T P=\frac{\sum_{i}^{n} W i}{n}
$$

\section{Description:}
EWTP : Average value of WTP tourist
Wi : WTP value each tourist
i $\quad:$ Number of respondent who willing to pay
$\mathrm{n} \quad$ : Number of respondent

\section{Result and discussion}

\subsection{The classical assumption test}

Multiple linear analysis models can be relied upon if they meet the criteria of the Best Linear Unlock Estimator (BLUE). The model must meet several criteria such as normal distribution, homogeneous variance, and linear. Identification of the achievement of the criteria in the model can be done with a classical assumption test [7]. The classical assumption tests conducted are normality test, heteroscedasticity test, and multicollinearity test.

Normality test is conducted to identify whether the residual value in the data has a normal distribution or not [8]. Normality testing process is done through regression calculations using the P-Plot in SPSS. Figure 3 shows that data that spreads around the diagonal line and follows the direction of the diagonal line which mean data meets the assumption of normality [9].

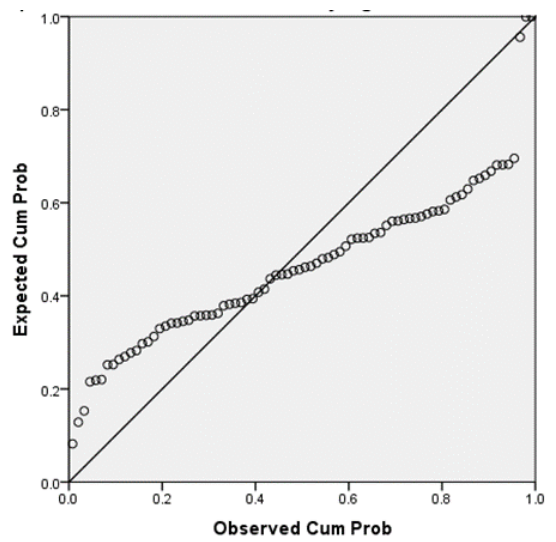

Fig. 3. Normality Test using P-Plot

Heteroscedasticity test is performed to identify whether there is an inequality of residual variance in a regression model [10]. Heteroscedasticity test results listed in Fig. 4 and shows that the points are scattered above or below the number 0 on the $\mathrm{Y}$ axis and do not form a clear pattern. This explains that the regression model meets the assumption because there is no heteroscedasticity.

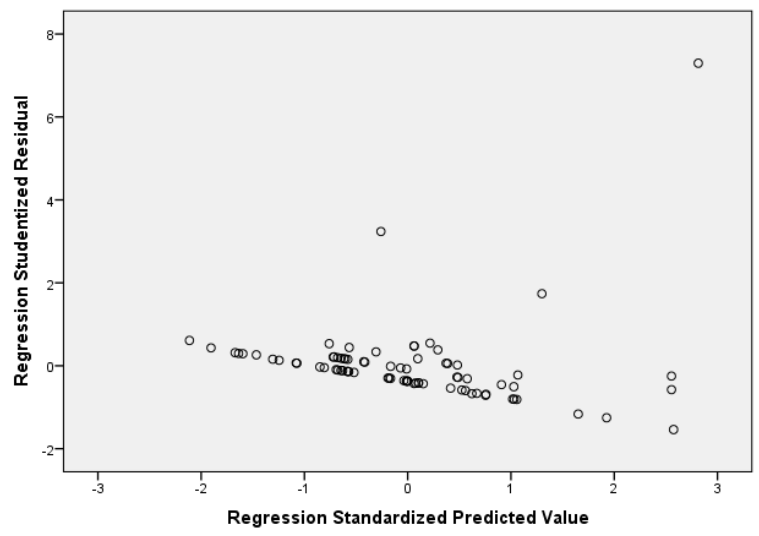

Fig. 4. Heteroskedasticity Test using Scatterplot 
Multicollinearity test serves to determine the level of correlation between independent variables in a regression model. Based on the multicollinearity test results listed in Table 1. it is known that the Tolerance value on all independent variables is quite close to the value of 1 and is in the range of 0.3 to 0.9 . Variance Inflation Factor (VIF) values for all independent variables are also around the value of 1 with a range of values $1-2.5$. This value indicates that the regression model does not have multicollinearity problems [11]. Based on the assumption test results it is known that the regression model has fulfilled the criteria so that the data can be used further.

Table 1. Multicollinearity Test Summary

\begin{tabular}{llrr}
\hline \multirow{2}{*}{ Model } & \multicolumn{2}{c}{ Collinearity Statistics } \\
\cline { 2 - 4 } \multicolumn{1}{l}{$\mathbf{1}$} & Tolerance & VIF \\
\cline { 2 - 3 } & Constant) & .938 & \\
\cline { 2 - 3 } & Travel Cost & .533 & 1.066 \\
\cline { 2 - 4 } & Age & .391 & 1.876 \\
\hline Education Degree & .451 & 2.555 \\
\hline Income & .941 & 1.062 \\
\hline
\end{tabular}

\subsection{Economic valuation of Blue Lagoon}

Regression model in the multiple linear regression analysis shown in Table 1. shows that the coefficient of determination of $\mathrm{R}$ Square is 0.145 . This value indicates that the independent variable can explain the variation in the dependent variable which is frequency of tourist visitor by $14.5 \%$. There are other variables which are not used in this study which have an influence on the frequency of tourist visitor. Distance is one of many factors that influence the level of tourist desire to come back visitor tourism place Hadi [6]. Blue Lagoon is located quite far from the city center and is not a major tourist destination. Based on the results of interviews with managers, Blue lagoon is not a main chioce from tourist attractions such as Kaliurang, Kaliadem, and Prambanan Temples. This case makes some tourists choose to visit other destination to avoid additional travel costs and travel time [12].

Table 2. Multiple Linear Regression Summary

\begin{tabular}{llrr}
\hline \multirow{2}{*}{ Model } & \multicolumn{2}{c}{$\begin{array}{c}\text { Unstandardized } \\
\text { Coefficients }\end{array}$} \\
\cline { 2 - 4 } & \multicolumn{2}{c}{$\mathrm{B}$} & Std. Error \\
\hline $\mathbf{1}$ & (Constant) & 2.039 & 2.508 \\
\cline { 2 - 3 } & Travel Cost & $-6.558 \mathrm{E}-06$ & .000 \\
\cline { 2 - 3 } & Age & .134 & .048 \\
\hline Education & -1.180 & .578 \\
Degree & & \\
\hline Income & $-6.385 \mathrm{E}-08$ & .000 \\
\hline Trip Duration & .809 & .510 \\
\hline $\mathbf{R}^{\mathbf{2}}: 0.145$ & & \\
\hline
\end{tabular}

Economic valuation using the travel cost method is carried out using multiple linear analysis to determine the influence function of independent variables on the dependent variable. The function is then used as a basis for calculating the value of consumer surplus. There are five independent variables used, namely the cost of travel, age, level of education, income, while the dependent variable used is the frequency of visitor in one year. Based on the test summary in Table 2, the following regression equation is illustrated below:

$$
\begin{gathered}
Y=-0,000006558 X 1+0,134 X 2-1,180 X 3- \\
0,00000006385 X 4+0,809 X 5+2,039
\end{gathered}
$$

The regression equation shows there are variables that have positive coefficient values such as age and trip duration and there are variables with negative coefficient values such as travel costs, education degree, and income. Negative coefficient value on the variable travel costs indicates that the economic theory of the relationship between price and demand applies to Blue Lagoon tourism. The theory explains that tourists will tend to choose to travel at a lower cost $[6,13]$

Function of travel costs in the regression analysis model purposed calculate value of consumer surpluses. The consumer surplus is calculated by carrying out the integral with the lower limit in the form of the lowest travel costs while the upper limit in the form of the highest travel costs incurred by tourists when traveling in the Blue Lagoon Tourism Village. Based on the data obtained, it is known that the lowest value of travel cost is IDR 10000 while the highest value of travel cost is IDR 380000 that configurate integral formula is obtained as follows:

$$
c S=\int_{10000}^{380000} 2.039-0.000006558 X 1
$$

Consumer surplus value obtained from the above calculation is IDR 281270 per individual per year. The average frequency of visitor in one year is 2.28 times, so it is known that the value of the consumer surplus per individual per visit is IDR 123 364. This value is higher than the average value of actual travel costs incurred by tourists which is IDR 36 950. Consumer surplus is the differences between tourist satisfaction with the costs that must be paid Priambodo and Suhartini (2016). This explains that tourists in the "Blue Lagoon" Tourism Village get the benefits of environmental services greater than the actual costs incurred [14].

Potential economic value in Blue Lagoon Tourism Village is calculated by multiplying the value of the consumer surplus with the average number of tourists. Average number of tourists visiting Blue Lagoon since it was first opened in the period 2014 - 2019 was 48791 visitor. Based on these calculations, it is known that the value of economic potential using the travel cost method of Blue Lagoon Tourism Village reaches IDR 6019052 924. Calculated using the same formula, the actual economic value is known to be IDR 1802827450 or $23.05 \%$ of economic potential. Absorption of economic potential that is still below $30 \%$ is due to the lack of interest in visitors spending their 
money on some services such as food stand or in the rental swimming equipment.

Economic potential value still smaller than on other natural attractions. Indonesian Karst Museum at Wonogiri Regency received an economic potential value of IDR 12239637293 in 2018 while Kusuma Agro Tourism, Batu City have potential economic value IDR 35908000 000. Lower economic potential in the Blue Lagoon Tourism Village when compared to existing natural tourism objects caused by the differences of average visit. Indonesian Karst Museum and Kusuma Agro Tourism reaches 78421 visitor per yr and 305600 visitor per yr, while Blue Lagoon depends on 48789 visitor per yr. The difference in the number of tourist visitor is caused by several factors such as promotions that and difference in the capacity of tourism attractions [6].

\subsection{Bequest value of Blue Lagoon}

Bequest value is an estimate of willingness to pay from tourists for environmental conservation in order to preserve sustainability for future generations [15]. Calculation of bequest value is important to do to continue to preserve the environment around Blue Lagoon Tourism Village and to carry out maintenance at existing facilities. Figure 5 shows that one of the facilities in Blue Lagoon was damaged during the rainy season at the end of March 2020. Policies taken from calculating the bequest value can be used to repair damaged facilities.

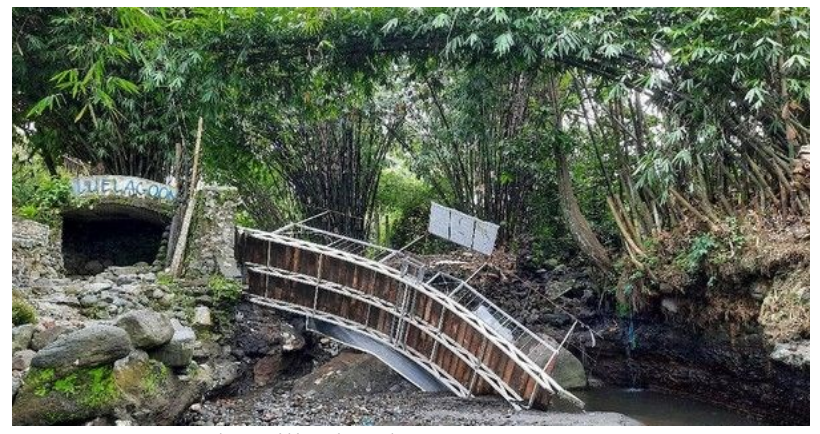

Fig. 5. Damaged Facility in Blue Lagoon

Bequest value of Blue Lagoon Tourism Village is obtained using the Contingent Valuation Method (CVM) by calculating the willingness to pay (WTP) of each tourist respondent. Based on the calculation results shown in Figure 6 there are $53(66.25 \%)$ people who are willing to pay for inheritance, while 27 people $(33.75 \%)$ are not willing to pay. The number also indicates that tourists still have awareness to protect and preserve the environment from the Blue Lagoon Tourism Village.

Based on the data in Table 3 it is known that the highest value obtained is IDR 100000 with a frequency of 1 person while the lowest is IDR 0 that is respondents who are not willing to pay with a frequency of 27 person. The most WTP values are in the figure IDR 10000 with a frequency of 14 person. According to statements from several respondents, the value of IDR 10000 per visitor is an appropriate value which means it is neither too high nor too low to be allocated for the conservation program of Blue Lagoon.

\section{Comparation WTP Bequest Value}

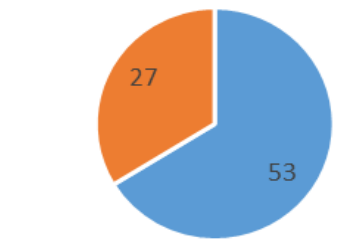

- Willing to pay $\quad$ Not willing to pay

Fig. 6. Diagram of Comparation WTP Bequest Value

Table 3. Frequency of WTP Value

\begin{tabular}{lr}
\hline WTP (Rp.) & Frequency \\
\hline 0 & 27 \\
\hline 2000 & 3 \\
\hline 5000 & 11 \\
\hline 10000 & 14 \\
\hline 15000 & 4 \\
\hline 20000 & 9 \\
\hline 25000 & 2 \\
\hline 30000 & 2 \\
\hline 50000 & 7 \\
\hline 100000 & 1 \\
\hline Total & 80 \\
\hline
\end{tabular}

Bequest value is estimated by multiplying between the average value of WTP of IDR 12513 with an average number of tourists visits of Blue Lagoon in the last $5 \mathrm{yr}$ amounting to 48791 visitor. The results of these calculations obtained a bequest value of IDR 610521783 per yr. As for Blue Lagoon tourist area has 6.45 ha, it is known that bequest value is IDR 94650758 per year per hectare. Calculation of bequest value in more detail can be seen in Table 4 . below.

Table 4. Bequest Value Calculation Summary

\begin{tabular}{lr}
\hline Variable & Value \\
\hline Average WTP (Rp.) & 12513 \\
\hline Average Visitor (People) & 48791 \\
\hline $\begin{array}{l}\text { Area Blue Lagoon Tourism } \\
\text { Village (Ha) }\end{array}$ & 6.45 \\
\hline Total Bequest Value (IDR/yr) & 610497388 \\
\hline Bequest Value (IDR) (ha/yr) & 94650758 \\
\hline
\end{tabular}

\section{Conclusion}

Consumer surplus value obtained from the calculation in this research is IDR 281270 per individual per year while average frequency of visitor in one year is 2.28 times, so it is known that the value of the consumer surplus per individual per visit is IDR 123 364. Potential 
economic value of Blue Lagoon Tourism Village is obtained by multiplying the consumer surplus with an average tourist visit and obtained by. IDR 6019052924 per year. The actual economic income of IDR 1802827450 or $23.05 \%$ of economic potential. Absorption of economic potential that is still quite low is due to the lack of interest in visitors spending their money on some services. Improving services and facilities is one of the keys to optimizing economic potential.

Willingness to pay (WTP) for bequest value of Blue Lagoon Tourism Village have average IDR 12513 with highest value IDR 100000 and lowest value IDR 0 (person who not willing to pay). Most WTP value is IDR 10000 with 14 person. Bequest value is estimated by multiplying between the average value of WTP with an average number of tourists visits of Blue Lagoon in the last 5 years with value of IDR 610521783 per year. Blue Lagoon Tourism Village has 6.45 ha of area, so bequest value based on area is IDR 94650758 . Bequest value of Blue Lagoon is important to calculated in order to preserve the environment and to carry out maintenance at existing facilities.

This paper is a part of the undergraduate thesis conducted by Fikri Nurrachman Ernawan under the guidance of Dr. Rika Harini, M.P. in the Faculty of Geography, Universitas Gadjah Mada. The Authors are grateful for the financial assistance and support through the "Rekognisi Tugas Akhir (RTA) 2020" program by DPP Universitas Gadjah Mada which really helps the process of research. Gratitude are also given to the Faculty of Geography, Universitas Gadjah Mada for the facilities that can be used to support the research process.

\section{References}

1. V.L Sabon, M.T. Perdana, P.C. Koropit, W.C. Pierre, ASEAN Eco. Com. 8, 163-76 (2018).

2. A. Sulistyowati, Impact of Blue Lagoon Tourism Village on Community Income, Universitas Gadjah Mada, Yogyakarta, (2019)

3. A. Sugianto, Ekuilibrium. 11, 56 (2016)

4. S. Febriani, Geo Educasia. 2, 6 (2017)

5. Akdon, Riduwan, Rumus Dan Data Dalam Analisis Statistika. (Alfabeta, Bandung, 2010)

6. $\quad$ S.P. Hadi, J. Ilm. FEB. 4, 1 (2015)

7. M. Jainuri. Data Analysis Test Requirements With SPSS (STKIP YPM Bangko, Jambi, 2019)

8. A. Apriyono, A. Taman. Nom. Bar. Ris. Akun. Mnjmn. 2, 76-96 (2013)

9. Nurmala, J. Eco. Mng. Bsn. 14, 221-233 (2013)

10. N. Maharani, Sudrajat. 2018. Jrnl Bumi Ind.7, 3 (2018)

11. Haslinda, J. Muhammad, Jrnl. Ilmiah Akun. Prdbn. 11, 10. (2016)

12. A. Arsalan, E. Gravitiani, H. Irianto. Seminar Pendidikan Biologi. 505-11 (2018)
13. O. Priambodo, Suhartini, Habitat 27, 122-32 (2016).

14. F. Zulpikar, D.E. Prasetyo, T.V. Shelvatis, K.K. Komara, M. Pramudawardhani, M 2017. J. Reg. and Rural Dev. Plan. 1, 53 (2017)

15. H. Tresnadi, J. Teknologi 1, 38-53 (2000) 